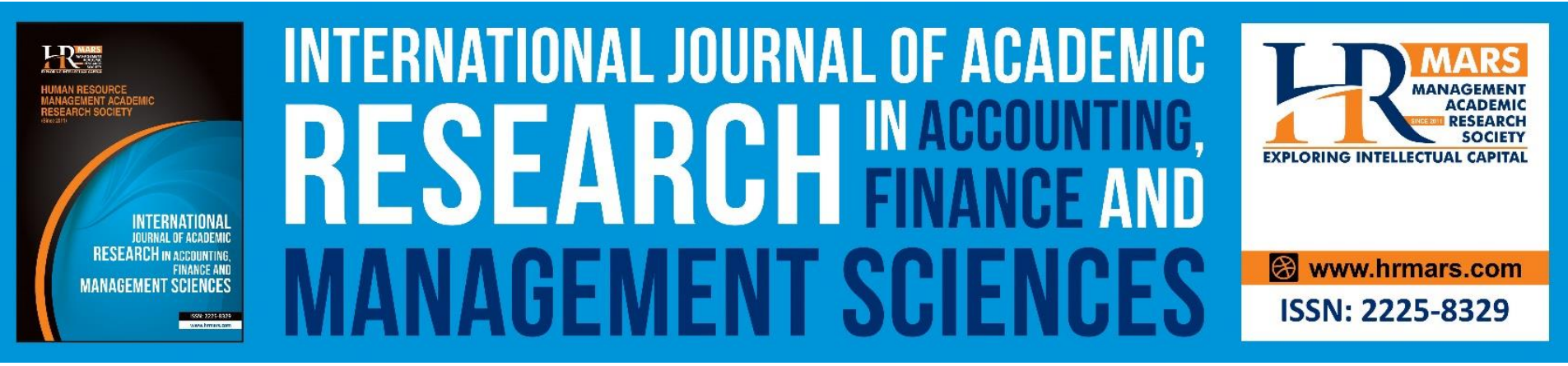

\title{
Analyzing the Effects of the Growth of ICT and the Education Sector on the Growth of the Industrial Sector: A Case Study of Jordan
}

Ateyah Mohammad Alawneh

To Link this Article: http://dx.doi.org/10.6007/IJARAFMS/v11-i1/9551 DOI:10.6007/IJARAFMS/v11-i1/9551

Received: 17 January 2021, Revised: 19 February 2021, Accepted: 05 March 2021

Published Online: 28 March 2021

In-Text Citation: (Alawneh, 2021)

To Cite this Article: Alawneh, A. M. (2021). Analyzing the Effects of the Growth of ICT and the Education Sector on the Growth of the Industrial Sector: A Case Study of Jordan. International Journal of Academic Research in Accounting Finance and Management Sciences, 11(1), 381-406.

Copyright: (C) 2021 The Author(s)

Published by Human Resource Management Academic Research Society (www.hrmars.com)

This article is published under the Creative Commons Attribution (CC BY 4.0) license. Anyone may reproduce, distribute, translate and create derivative works of this article (for both commercial and non-commercial purposes), subject to full attribution to the original publication and authors. The full terms of this license may be seen

at: http://creativecommons.org/licences/by/4.0/legalcode

Vol. 11, No. 1, 2021, Pg. 381 - 406

http://hrmars.com/index.php/pages/detail/IJARAFMS

JOURNAL HOMEPAGE

Full Terms \& Conditions of access and use can be found at http://hrmars.com/index.php/pages/detail/publication-ethics 


\title{
Analyzing the Effects of the Growth of ICT and the Education Sector on the Growth of the Industrial Sector: A Case Study of Jordan
}

\author{
Dr. Ateyah Mohammad Alawneh \\ Tafila Technical University, College of Business, AT-Tafila, Jordan
}

\begin{abstract}
The study aims to discuss and analyze the effects of the growth of the information and communications technology (ICT) and the education sectors on the growth of the industrial sector for companies listed on the Amman Stock Exchange during the period of 2005-2019. This study took total assets as an indicator of the sector's growth and the data used relied on the guidance of companies listed in the Amman Financial Market for the variables of the study. The E-views program was used for statistical analysis. The results of the VAR analysis indicated the existence of a reciprocal relationship between the growth of the ICT, the education, and the industrial sectors. The study also conducted a short-term analysis of the response functions and analysis of variance, and found a positive effect of the growth of ICT on the growth of the industrial sector in the short term. In addition, the results of the co-integration analysis through the Johansen test indicated a long-term equilibrium relationship between the growth of the telecom, the education, and the industrial sectors. Moreover, regression analysis based on the results of the vector autoregression model showed a positive statistically significant relationship between the growth of the ICT and the industrial sectors. The analysis also showed the existence of a positive statistically significant relationship between the growth of the education and the industrial sectors. Among the most important recommendations of the study is the need to pay attention and increase spending on the growth of the ICT and the education sectors to increase the growth in the industrial sector and other basic economic sectors to stimulate growth in the country. Foreign and domestic investment in the main sectors of technical and technological education should be increased to allow it to grow significantly and taking care of human resources that lead to the promotion of growth in basic sectors. Attention should be given to the experience of East Asian countries, such as Japan and South Korea in linking education with the application of technological innovation.
\end{abstract}

Keywords: Telecommunications, Technology, Education, Growth, Industry, Total Assets

\section{Introduction}

The ICT and education sector are the two main drivers of growth and prosperity of the economies of most countries of the world. They are also considered the main source that provides the economy with education and training and the use of means to communication and information. 
INTERNATIONAL JOURNAL OF ACADEMIC RESEARCH IN ACCOUNTING, FINANCE AND MANAGEMENT SCIENCES

Vol. 11, No. 1, 2021, E-ISSN: 2225-8329 @ 2021 HRMARS

The major role that ICT plays through electronic payment methods the facilitate the ease of financing the industrial sector. However, will the growth in the size of the education sector affect the growth of the industrial sector?

Does the growth of ICT affect the growth of the industrial sector? Moreover, is there a joint complementarity between the growths in the sizes of the education, the ICT, and the industrial sectors? Many studies confirm the existence of a positive relationship between the growth of ICT and the increase in productivity and growth, but disagreement among developing countries has been observed on whether the growth in the telecommunications sector makes any difference (Aghaie et al., 2017). Moreover, the decline in the growths of the education and the ICT sectors leads to a decrease in growth of the industrial and service sectors and the economy as a whole. The decrease can be observed particularly in the industrial sector because of the great need for education services and information technology. Some studies have indicated that the decrease in the number of information and communications technology experts in European countries has led to a decrease in innovation activities in this region as compared to the United States of America, Japan, and Canada (Maryskaa, Douceka, and Kunstovaa, 2012). The education and the ICT sectors affect many sectors, which in turn has an effect on the industrial sector and the growth of economic sectors that are integrated manner with each other. For this reason, many countries have focused on the growths of the education and ICT sectors, such as South Korea, Japan, Asian countries, and developed European countries to support the industrial sector.

Jordan has the infrastructure and an advantage because it has invested in the growth of the education and the ICT sectors, especially in the age of the Internet. Investment has been made in technical, vocational, or applied education, which would provide support to the industrial sector through the acquisition of technical skills and other training tools. Technological education can also be advanced through the establishment of many technical institutes, colleges, and universities offering technical education. This issue has also become a basic topic in Jordan through the guidance of human cadres to technical and electronic education from the school stage. Opening training centers in schools to teach on the use of modern machinery and technologies and new industrial and technological equipment has become an important aspect that contributes to development and growth, especially in the industrial sector.

A clear interest on the part of higher education in Jordan is to link education with the practical side. The practice of many courses and specializations of interest enhances the growth and development of the industrial sector in Jordan by supporting the sector with trained and educated professional competencies.

These two sectors are complementary and a reciprocal relationship can be observed between the growth of the education sector and the growth of ICT and their effect on the growth of the industrial sector. They are also distinct and pioneering sectors in terms of influencing the growth of the Jordanian industrial sector. The education and the ICT sectors are among the most important items on the agenda of the Jordanian government today. The telecommunications sector includes digital telephone network, mobile phones, internet capability, internet servers, fixed broadband, and other technologies.

This study considers the education, technology, and communications sectors to be among the service sectors that contribute significantly to the gross domestic product, and for this reason, their roles are important in the Jordanian national economy. To the best of this researcher's knowledge, this study is one of the rare studies that analyzes the effects of the education, technology, and communications sectors on the growth of the industrial sector in Jordan. An analysis will be conducted using the vector 
INTERNATIONAL JOURNAL OF ACADEMIC RESEARCH IN ACCOUNTING, FINANCE AND

MANAGEMENT SCIENCES

Vol. 11, No. 1, 2021, E-ISSN: 2225-8329 @ 2021 HRMARS

autoregression model. The short-term effect will be identified through the analysis of response functions and analysis of covariance, as well as knowledge of the long-term equilibrium through cointegration analysis. Statistical tests will also be conducted to ensure the integrity of the model. The study relied on the growth criterion using the total assets index to indicate the growths of the education, the ICT, and the industrial sectors in Jordan. The study will be divided into four parts. The first part introduces the study, the second part addresses the previous studies and theoretical framework, the third part provides the statistical analysis of the study, and the fourth part provides the results and recommendations.

\section{Study Problem}

The study problem comes from the practical reality of ICT and the education sector, which are considered to be among main driving sectors and the most important sectors in Jordan's agenda that can be relied upon in the growth of vital business in Jordan, especially the industrial sector, which is one of the most important sectors in Jordan and one of the basic sectors for growth and progress. The study problem can be formulated through the following questions.

1. What is the effect of the growth of ICT on the growth of the industrial sector for companies listed on the Amman Stock Exchange?

2. What is the effect of the growth of the education sector on the growth of the industrial sector for companies listed on the Amman Stock Exchange?

3. Does the growth of ICT affect the growth of the industrial sector in the short term?

4. Does the growth of the education sector affect the growth of the industrial sector in the short term?

5. Is there a long-term co-integration relationship of statistical significance between the growth of the ICT, the education, and the industrial sectors.

\section{Hypotheses of the Study}

1. A statistically significant positive relationship at $(\alpha \geq 0.05)$ between the growth of the ICT sector and the growth of the industrial sector exists.

2. A statistically significant positive relationship at $(\alpha \geq 0.05)$ between the growth of the education sector and the growth of the industrial sector exists.

3. A short term positive relationship between the growth of ICT and the growth of the industrial sector can be observed.

4. A short-term positive relationship between the growth of the education sector and the growth of the industrial sector can be observed.

5. A statistical significance of a long-term co-integration relationship at $(\alpha \geq 0.05)$ between the growths of the technology and telecommunications sector, the education, and the industrial sectors.

\section{Importance of the Study}

The importance of the study lies in that fact that it sheds light on the important sectors in the Jordanian economy. Its practical importance comes from conducting an impact analysis of the ICT and education sectors, which are considered among the most important sectors in the Jordanian economy and the two main drivers of economic growth and development in the economy as a whole and the industrial sector. In particular, study can assist decision-makers in the Jordanian economy in planning for the future growth of the industrial sector by focusing on the growth of the ICT and education sectors. Therefore, this study will be beneficial to the government's agenda of achieving 
INTERNATIONAL JOURNAL OF ACADEMIC RESEARCH IN ACCOUNTING, FINANCE AND

MANAGEMENT SCIENCES

Vol. 11, No. 1, 2021, E-ISSN: 2225-8329 @ 2021 HRMARS

growth in the industrial sector. This study will also obtain results that can help decision-makers and economic policymakers in Jordan in the process of growth and stimulation of the industrial sector.

\section{Objectives of the Study}

The study aims to achieve the following objectives:

1. Analyze the interrelationship between the growth of ICT and growth of the Jordanian industrial sector using the vector autoregression model.

2. Analyze the interrelationship between the growth of the education sector and the growth of the Jordanian industrial sector using the vector autoregression model.

3. Analyze the effects of the growth of ICT on the growth of the industrial sector based on the results using the vector autoregression model.

4. Discover the short-term effects of the growth of ICT on the growth of the industrial sector.

5. Find a long-term balance between the growth of the ICT, the education, and the industrial sectors through the co-integration of Johansson.

6. Provide results and recommendations that will help economic decision-makers plan for growth in the economic sectors in Jordan.

\section{Study Methodology}

This study adopted the descriptive and analytical method in carrying out this research while the study data were obtained through the Amman Financial Market website, and the study sample, which includes all industrial companies listed in the Amman Financial Market is the accumulated financial data. The total assets were as an indicator of the sector's growth based on some studies. The E-views program is used for the following statistical analyses: the vector autoregression model to identify the interrelationship between the variables; the response functions and covariance analysis to determine the short-term effect; the co-integration of the Johansson test to find equilibrium on a long-term level; and the multiple linear regression (OLS), which depends on the results of VAR.

Models of the Study Independent variables

Dependent variables
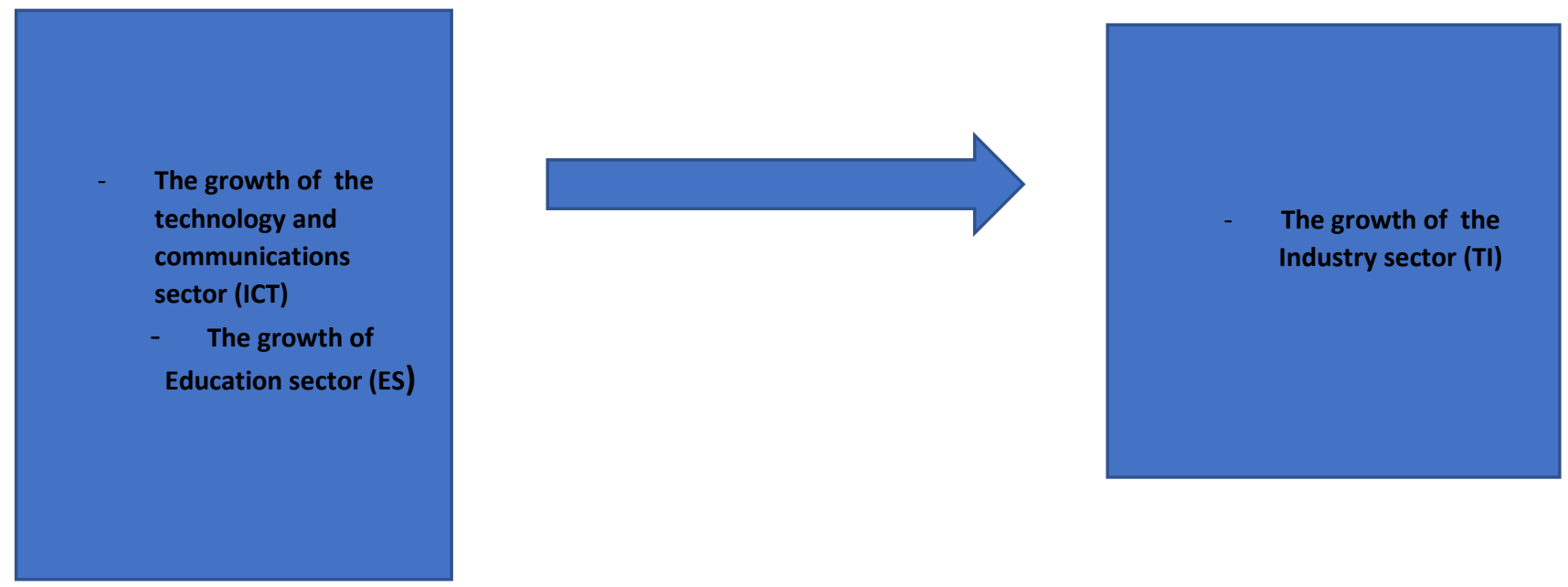
INTERNATIONAL JOURNAL OF ACADEMIC RESEARCH IN ACCOUNTING, FINANCE AND

MANAGEMENT SCIENCES

Vol. 11, No. 1, 2021, E-ISSN: 2225-8329 ๔ 2021 HRMARS

\section{Previous Studies and Theoretical Framework \\ Previous Studies}

Many studies have attempted to clarify the effects of technology on economic growth and some macroeconomic variables. For instance, Elena, Angela \& Sorin (2018) assessed the effects of information technology on the economic growth of the European Union during the period of 20002017 using panel-data estimation techniques and found a strong positive relationship for information technology and economic growth in the European Union. The study revealed that information technology, in addition to other macroeconomic factors, is an important engine for economic growth in the European Union. Among the most important recommendations of the study is the need to encourage investment in this sector and encourage studies in this field in the European Union and other countries. Raéf \& Alaa (2019). explored the effects of ICT on the economic growth of selected developing countries in the Middle East, North Africa (MENA), and Sub-Saharan Africa (SSA) using a generalized panel of the growth of the moment method (GMM) model during the period 2007-2016. The analysis showed the existence of a positive effect of information technology on the economic growth of all countries in the study sample. Thus, one of the most important recommendations of the study is that countries should give priority to allocating resources for the development. Ghaei, \& Rezagholizadeh (2017) investigated the causal relationship between ICT and the economy through its application to the economy of countries in the Organization of Islamic Cooperation (OIC) during the period from 1990-2014. The analysis revealed the significant effect of investments in ICT on economic growth in the countries in the study sample and that there was a need to provide financial support to strengthen the infrastructure in the OIC countries and to bridge the gap between the OIC countries in the field of information technology. Pradhan, et al. (2018) clarified the relationship between information and communication technology infrastructure and per capita gross domestic product, in the G-20 and found the existence of a relationship between the increase in ICT infrastructure and the increase in the per capita share of the gross domestic product. The study recommended that the infrastructure base be expanded, given great attention and modernized . Maryam et al. (2012) look into the effects of use of information and communication technology on economic growth. The results showed that the use of information and communication technology has a significant impact on the economic growth of these countries where one of the most important recommendations of this study was to give more attention in the future to more studies on this topic. Faris, Syed \& Mohamed (2019) seeks to identify the effects of ICT on the financial development index of the Gulf Cooperation Council countries during the period 2000-2016, as the study relied on the index of the ratio of credit to the private sector on the gross domestic product and the ratio of the money supply to the gross domestic product as indicators of financial development, as the statistical study showed the existence of A positive relationship between communications, information and indicators of financial development one of the most important recommendations of the study was coordination between the telecommunications and information sector, the energy sector, and the growth policy, which is necessary, important and vital in the countries of the Gulf Cooperation Council and as a catalyst for financial development.

Another strand of literature analyzes the effects of ICT in The Contribution Of The ICT Sector In The Economic Development Nashat, et al. (2017), the study aims to clarify the contribution of the information and communication technology sector to the economic development process, as the statistical analysis of the study showed a positive relationship that shows that the progress of the information technology sector contributes significantly to providing solutions to problems, increases the productivity and efficiency of companies, supports decision-making systems, and reduces costs 
INTERNATIONAL JOURNAL OF ACADEMIC RESEARCH IN ACCOUNTING, FINANCE AND MANAGEMENT SCIENCES

Vol. 11, No. 1, 2021, E-ISSN: 2225-8329 @ 2021 HRMARS

as well to increase trade and reduce cost and effort, and one of the most important recommendations of the study is the necessity to develop communications and information technology in line with global development and develop an interest in the sector through increased investment

There are many studies on the effect of education on growth and some other economic variables, including that of Eric \& Ludger (2007), study aims to clarify the role of education in promoting economic well-being, with a special focus on the role of education quality. The study concluded that there is a major role for education and basic skills of the population is increasing individuals' income, profits, and increasing economic growth in the country, and that the quality of education has a major role in influencing economic growth one of the most important recommendations of the study was to pay attention to the quality of education through the primary concern of the teacher and the provision of basic resources for that. Chong-S \& Min-K (2010), study aim to clarify education policy and industrial development in Korea and Mexico as the study shows that providing workers in Korea with an adequate level of education was present at every stage of development, while in Mexico, the supply of industrial sectors with educated workers was not compatible with the demand for labor derived from the structure the study concluded that the effective use of education spending has a major role in affecting economic growth, not the volume of spending.

Some studies also show the role of the education sector in creativity and innovation as Adekunle \& Fatima (2020) The study aims to clarify the role of the education sector in increasing technological innovations in Africa, as the analysis of the study showed that there is an important role for the education sector in technological innovations, as there is a mutual relationship between the education sector and technological innovations in Africa, and one of the most important recommendations of the study was to develop a comprehensive strategy that goes beyond education Present. Dalia (2017) aims to clarify the effect of the services sector on economic growth in Palestine for the period (2000-2016), as the study relied on analysis using the e-views program and the SPSS program the results of the analysis showed a strong relationship between the growth of the services sector and the growth of the industrial sector, as there is a strong complementary relationship between the two sectors, and the education sector had a strong impact on the growth of services section the most important recommendations were the need to pay attention to productive services, such as telecommunications and information, to address structural distortions in the economy. Francis (2020) The study aims to analyze the entrepreneurship education curriculum and methods of implementing it in higher education institutions in Nigeria, where the size of the study sample of 384 university students was determined The results of the analysis showed that entrepreneurship education is ineffective due to poor education, poor infrastructure, corruption, poor funding, and curricula are ineffective in developing entrepreneurship in Nigeria, and one of the most important recommendations of the study was to provide places for entrepreneurship education through small enterprises and employ opportunities for education not traditional. Adel ( 2013)., The study aims to clarify the contribution of the education sector to industrial development in Arab countries one of the most important results of the study is that Arab countries suffer from a gap in teaching the use of computers and how to benefit from information and communication technology in current and future work in the various required disciplines. Another strand of literature analyzes the impact of investment in education on economic growth as, Mohun et al (2010), The study aims to clarify the impact of investment in education on economic growth in Mauritius during the period 1990-2006, by using data on human capital and production where the analysis revealed that investment in human capital through education leads to enhanced productivity, which plays an important role in Increased 
INTERNATIONAL JOURNAL OF ACADEMIC RESEARCH IN ACCOUNTING, FINANCE AND MANAGEMENT SCIENCES

Vol. 11, No. 1, 2021, E-ISSN: 2225-8329 @ 2021 HRMARS

growth and Sylvie et al. (2018) The study aims to demonstrate the relationship between education and economic growth in India through the use of the causal relationship and co-integration, as it was evident from the standard analysis that there is a positive relationship between education and growth in India and one of the most important recommendations of the study was the necessity to find a comprehensive equation to calculate the stock of human capital that which includes More variants.

\section{Features of the Current Study}

Some previous studies analyzed the effects of investment on ICT on economic growth as well as the effects of investment in the communications technology sector on economic growth. Some studies also shed light on spending and investment in the education sector on economic growth or the effect of education sector on economic growth.

While this study will analyze the effects of the growth of the telecommunications sector and the growth of the education sector on the growth of the industrial sector during the period (2005-2021) In Jordan, by using total assets as an indicator of the sector's growth and what is characteristic of this study, the use of a modern analysis method by analyzing the reciprocal relationship and the impact analysis based on var results and finding the long-term co-integration between the growth of ICT sector, the growth of the education sector and the growth of the industrial sector in Jordan and finding a short-term effect through response functions and common variance analysis, as it is one of the rare studies to the extent of the researcher's knowledge of taking into account ICTs and education sector in the impact on the industrial sector.

\section{Theoretical Framework}

\section{Measuring Corporate Growth}

The growth approach is a complex process because it can measure many views using measures of size, while another section considers that the growth of companies can be measured through a quantitative increase in inputs, such as total assets, property rights, and employment, while some use an increase in outputs such as sales, profits, and cash flows.

The multiple dimensions of growth come in the selection of standard indicators consistent with the study objectives and the nature of growth, for example, Honjo and Harada (2006) relied on total assets as an indicator of corporate growth because total assets are a measure of growth that all companies seek to increase assets and increase company size (Bousaba \& Sari (2016). Shukiri \& Walid (2009), 2009 took the total assets index to denote the size of the company. The current study will use total assets as an indicator of company growth because asset growth is sought by all companies to increase company size.

\section{Relationship between the Study Variables.}

Some economists are aware of the importance of education in the growth of the industrial sector and economic growth in the country, and a positive relationship between the education sector and economic growth has been observed, which resulted in the state increasing spending in education as seen by Fred Marshall. The economist, Theodore Schultz, also stressed the importance of education and the development of economic resources through education and training.

Numerous studies have revealed the importance of spending on education and human resources in technological development and interest to increase productivity in many countries. Education also has a great role in the development of industries and technology and in the development of 
INTERNATIONAL JOURNAL OF ACADEMIC RESEARCH IN ACCOUNTING, FINANCE AND MANAGEMENT SCIENCES

Vol. 11, No. 1, 2021, E-ISSN: 2225-8329 ๑ 2021 HRMARS

developing countries into the ranks of developed countries, such as the experience of South Korea, which focused on education, training, and the education sector in human resources Adel (2013, pp 52-54). Studies also indicated the great role that the education sector plays in increasing growth and development Eric \& Ludger (2007) and in investing in human resources (Mohun et al. 2010) . Cointegration between the education sector and growth in general has also been explored (Sylvie et al., 2018).

Some studies have also referred to the mutual influence of the education sector on the development, innovation, and creativity, and on the ICT sector (Adekunle \& Fatima, (2020). Several studies have reported the a close correlation between the development of the ICT sector and the development and growth of companies that use communication and information technology, which reached $76 \%$ (Nashat 2017, p. 21).

Although the effect of education on the adaptation and use of new technology has been positive, but success has not been easy. The contribution of capital is a reality that is linked to technical progress with increased capacity to use technology and to adapt it to foreign policy rather than to develop domestic innovation, which indicates that the effect of education on growth and technological development is related closely to the degree of state openness (The World Bank, 2009)

Importance of the Growth of ICT and Growth of Education in the Growth of the Industrial Sector The technology sector is one of the important sectors in the national economy, as it is available the infrastructure for the technology sector in economic development by reducing transaction costs (such as providing financial services faster), creating new opportunities for innovation, providing access to new markets (for example through e-commerce and better exchange of information), and reducing the cost of capital (By increasing efficiency in the functioning of financial markets), bridging regional inconsistencies in income and productivity, providing capital (through remote networks), and generating positive externalities. Hence, as observed in advanced economies, also a strong infrastructure ICT is an essential precondition for promoting economic development by supporting industry, manufacturing, marketing, and sales, improving agriculture, education, health, social services, and transportation, as well as contributing to macroeconomic stability (Pradhan, R, et al, $2018, \mathrm{pp} 93)$. This indicates the existence of a reciprocal relationship between the education sector, information technology, and industry, as both of them need the other and are considered complementary to each other in economic fields as the development of education leads to the development of technology and communications, and the development of education leads to the development of industry and the development and economic progress in any Both of them positively affect other sectors, indicating the complementary relationship between the industry, education, technology, and communications sectors. As indicated by Dalia, M, S (2017) a strong complementary relationship between the services sector in general and the industrial sector can be formed. Several studies indicate a positive relationship between information technology and growth as a study Elena, et al (2018) (indicate year) study of Raéf \& Alaa (2019). Aghaei \& Rezagholizadeh (2017) and Maryam Rahmah \& Masood (2012). Some studies also indicate the role of the information technology sector in influencing development, reducing costs and increasing the growth rate, as Nashat (2017)

\section{Descriptive Analysis}

\section{Industrial Sector in Jordan and its Development}

The industrial sector is considered an essential pillar to support the national economy in Jordan, as it plays a major role in contributing to the GDP general statistics indicate that the direct contribution of 
INTERNATIONAL JOURNAL OF ACADEMIC RESEARCH IN ACCOUNTING, FINANCE AND MANAGEMENT SCIENCES

Vol. 11, No. 1, 2021, E-ISSN: 2225-8329 @ 2021 HRMARS

the industrial sector to the GDP through the manufacturing and mining industry amounted to about 25\% for the years 2011-2017. In addition to the indirect contribution to other economic sectors, the industrial sector is important in Jordan, due to its great contribution to the GDP and the provision of job opportunities in addition to providing training to workers, especially in the technical field. And the technical field

The exports of the industrial sector also contribute to reducing the Jordanian trade balance deficit, Therefore, its development is important for the development of other sectors directly or indirectly related it the industrial sector in Jordan includes the manufacturing sector, such as leather, plastics, chemicals, food, technological industries, etc. Industry in Jordan also includes the mining industry sector, which includes mining, quarrying, potash, cement, phosphates, limestone extraction, and other strategic mining industries in Jordan (Al-Halaiqa 2020)

Table (1) shows that the descriptive analysis of the average growth of the industrial sector during the study period was $(3.73 E+09) M J D$, where the highest value was $(4.40 E+09) M J D$ and its lowest value was $(2.60 E+09)$ MJD during same study period. Table 1 shows that the Jarque-Bera results indicate that the industrial sector data follow a normal distribution because the probability greater than $5 \%$.

Table No. (1) Descriptive statistical analysis of the industrial sector in Jordan during the study period.

\begin{tabular}{|l|l|}
\hline Descriptive statistical & TI \\
\hline Mean & $3.73 \mathrm{E}+09$ \\
\hline Median & $3.95 \mathrm{E}+09$ \\
\hline Maximum & $4.40 \mathrm{E}+09$ \\
\hline Minimum & $2.60 \mathrm{E}+09$ \\
\hline Std. Dev. & $5.58 \mathrm{E}+08$ \\
\hline Jarque-Bera & 2.816942 \\
\hline Probability & 0.244517 \\
\hline Sum & $5.59 \mathrm{E}+10$ \\
\hline Sum Sq. Dev. & $4.35 \mathrm{E}+18$ \\
\hline Observations & 15 \\
\hline Probability & 0.244517 \\
\hline Probability & 0.244517 \\
\hline Sum & $5.59 \mathrm{E}+10$ \\
\hline Sum Sq. Dev. & $4.35 \mathrm{E}+18$ \\
\hline Observations & 15 \\
\hline
\end{tabular}

Source: Prepared by the researcher using the E-views program based on the study data in Appendix no. (1).

The graph (1) shows the development of the industrial sector, the researcher note that the growth of the industrial sector continued to increase from 2005 until it reached its highest growth in 2011 with a value of (4401435385) JD, then the manufacturing sector started to decline and continued to decline in a volatile fashion until 2017 a value of (3761173287) JD then it continued to rise until the end of the study 
INTERNATIONAL JOURNAL OF ACADEMIC RESEARCH IN ACCOUNTING, FINANCE AND MANAGEMENT SCIENCES

Vol. 11, No. 1, 2021, E-ISSN: 2225-8329 @ 2021 HRMARS

Graph. (1): The development of the industrial sector during the study period

$\mathrm{TI}$

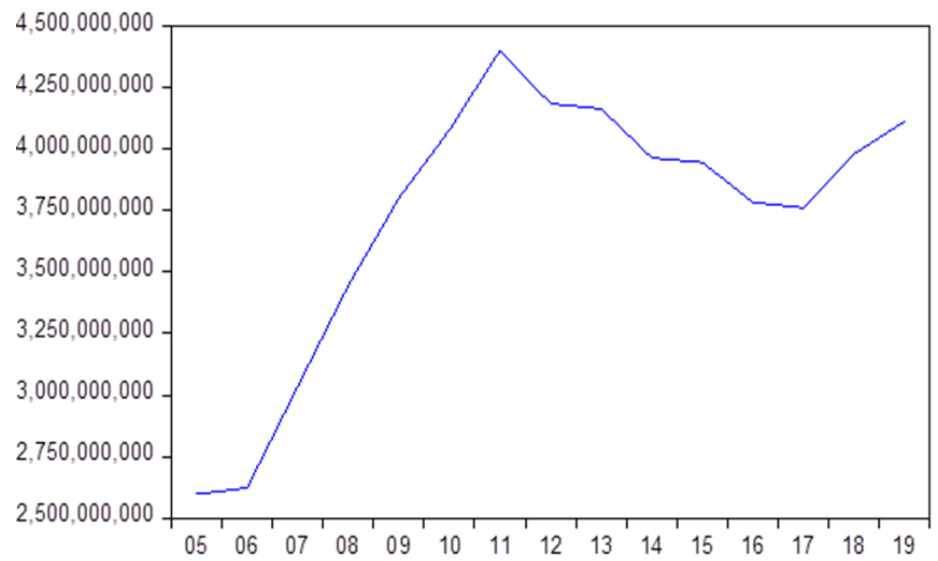

Source: Prepared by the researcher using the E-views program based on the study data in Appendix no. (1).

\section{ICT and Education Sectors in Jordan and its Development}

The Jordanian government greatly developed telecommunications, and for this purpose, it privatized Jordan Telecom. It sold its entire share in 2008, and France Telecom now owns 51\%. The government sold its other shares to some institutions and open competition to provide the best services in the field of telecommunications and technology. Several other companies have entered this field, including Zain, Orange, and Umniah, to develop the ICT infrastructure.

The ICT sector in Jordan is considered a smart step for the future because Jordan has succeeded in establishing and developing a highly competitive ICT sector, a pioneering sector in the MENA region, that is currently serving larger regional markets in the era of technology and innovation. The total revenues of the ICT sector for the year (2018) was 2.3 billion USD, the number of jobs offered in the ICT sector for the year (2018) was 22,413 , composed of $67 \%$ for males and $33 \%$ for females, mobile penetration rate was $85 \%$ for 2018 and $88.8 \%$ Internet penetration rate was $88.8 \%$ for 2018 . Jordan offers many incentives to support this sector, including reduced taxes, customs fees, and income taxes.

\section{ICT and Education}

Jordan set a regional example in modernizing and developing its educational system by launching many initiatives through partnerships of the public and private sectors to ensure that the outputs of the educational system meet the evolving requirements of the global economy and equip students with the tools of competition and excellence in the market (Ministry of Digital Economy, Information Technology in Jordan). Investment in human capital in Jordan, which includes higher education, general education, vocational and technical education, and training for the development and growth of the importance of education and its use in the growth process, following countries such as Singapore, South Korea, Finland, China, and Japan has also been made (Education and Development, Al-Rai Newspaper, 2014). 
INTERNATIONAL JOURNAL OF ACADEMIC RESEARCH IN ACCOUNTING, FINANCE AND

MANAGEMENT SCIENCES

Vol. 11, No. 1, 2021, E-ISSN: 2225-8329 @ 2021 HRMARS

Descriptive Analysis of the Growth of the ICT and the Education Sectors

Table (2) shows the average growth of the ICT sector in million dinars $(6.77 \mathrm{E}+08)$, where the highest value for the growth of the size of the ICT sector was $(7.61 \mathrm{E}+08) \mathrm{MDJ}$ and the lowest value was $(5.63 \mathrm{E}+08) \mathrm{MDJ}$. The average growth of the education sector for companies listed on the Amman Stock Exchange $(2.50 E+08)$ was one million Jordanian dinars, where the highest growth value for the education sector was $(3.16 \mathrm{E}+08) \mathrm{MJD}$ and the lowest value was $(1.68 \mathrm{E}+08) \mathrm{MJD}$ during the study period. The results of the the Jarque-Bera test shows that ICT I sector data follow a normal distribution because the probability greater than $5 \%$. The Jarque-Bera test shows that the education sector data follow a normal distribution because the probability is greater than $5 \%$.

Table No. (2) Descriptive statistical analysis of the ICT sector and the education sector in Jordan during the study period.

\begin{tabular}{|l|l|l|}
\hline Descriptive statistical & ICT & ES \\
\hline Mean & $6.77 \mathrm{E}+08$ & $2.50 \mathrm{E}+08$ \\
\hline Median & $6.87 \mathrm{E}+08$ & $2.61 \mathrm{E}+08$ \\
\hline Maximum & $7.61 \mathrm{E}+08$ & $3.16 \mathrm{E}+08$ \\
\hline Minimum & $5.63 \mathrm{E}+08$ & $1.68 \mathrm{E}+08$ \\
\hline Std. Dev. & 55904696 & 47554124 \\
\hline Jarque-Bera & 0.626169 & 1.141212 \\
\hline Probability & 0.731188 & 0.565183 \\
\hline Sum & $1.02 \mathrm{E}+10$ & $3.75 \mathrm{E}+09$ \\
\hline Sum Sq. Dev. & $4.38 \mathrm{E}+16$ & $3.17 \mathrm{E}+16$ \\
\hline Observations & 15 & 15 \\
\hline
\end{tabular}

Source: Prepared by the researcher using the E-views program based on the study data in Appendix no. (1).

The graph (2) shows the development of the growth of the ICT sector, which increased continuously from 2005 and continued to increase until 2009 by a value of (760863444) Jordanian dinars, then it began to decrease, fluctuating until it reached its lowest value in 2015 with a value of (607661116) Jordanian dinars, and ten it began to rise and fluctuate until the end of the study in 2019.

Graph (2) of the development of the growth of the size of ICT during the study period. ICT

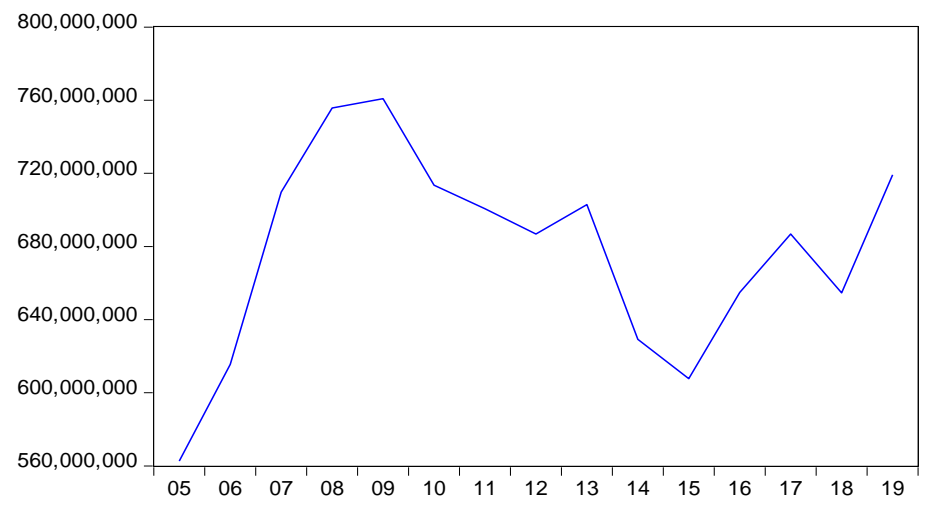

Source: Prepared by the researcher using the E-views program based on the study data in Appendix No. (1). 
INTERNATIONAL JOURNAL OF ACADEMIC RESEARCH IN ACCOUNTING, FINANCE AND

MANAGEMENT SCIENCES

Vol. 11, No. 1, 2021, E-ISSN: 2225-8329 @ 2021 HRMARS

The graph (3) shows that the growth of the education sector is generally increasing until it reached its highest value in 2015 (316276741) JD. However, the growth began to decline towards the end of the study.

Graph (3) of the development of the growth of the size of the education sector during the study period.

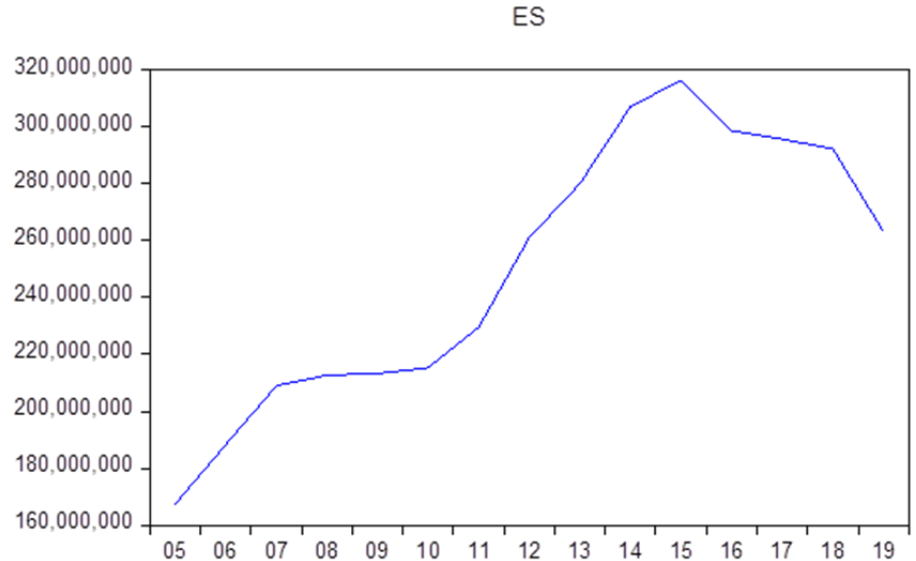

Source: Prepared by the researcher using the E-views program based on the study data in Appendix no. (1).

\section{Correlation between Study Variables}

Table 3 shows that the positive relationship between the growths of the industrial, the ICT and the education sectors for companies listed in the Amman Financial Market during the study period from 2005-2015.

Table No (3) the simple correlation between the variables of the study

\begin{tabular}{|l|l|l|l|}
\hline Variables & TI & ICT & ES \\
\hline TI & 1 & 0.42 & 0.63 \\
\hline
\end{tabular}

source: Prepared by the researcher using the E-views program based on the study data in Appendix no. (1).

\section{Statistical Analysis of the Study}

To reach the best results, the following statistical analysis methods will be conducted to obtain the best results. These methods include the vector autoregression model, analysis of response functions and covariance, Impact analysis based on results of the vector autoregression model and cointegration analysis through the Johansen test were conducted.

\section{Analysis of the Vector Autoregression Model \\ Deceleration Test for Study Variables}

The number of deceleration periods for the study variables will be determined to achieve the VAR analysis as follows.

The analysis was carried out according to Appendix 2, in which the tests indicated a choice of lag (2). as indicated by the FPE AIC SC HQ test. 
INTERNATIONAL JOURNAL OF ACADEMIC RESEARCH IN ACCOUNTING, FINANCE AND

MANAGEMENT SCIENCES

Vol. 11, No. 1, 2021, E-ISSN: 2225-8329 ๔ 2021 HRMARS

\section{Analysis of the Vector Autoregression Model}

With previous delay tests in Appendix 2, the vector autoregression model will be analyzed at lag (2), where the analysis was performed and the results were produced as in Appendix 3 as follows.

The results of VAR from the first column in Appendix 3 indicate a positive correlation between the growth of the industrial sector and the growths of the ICT and the education sectors.

The value of the F-statistic (22.89) indicates that the model is statistically significant because the coefficient of determination is $95.81 \%$. That is, $95.81 \%$ of the changes in the growth of the ICT and the education sectors explain the growth of the industrial sector.

The stability of the VAR model can also be confirmed by converting the model in the form in Appendix (4) )and unveiling the points within the unitary circle, which shows that the chains are stable.

\section{Response Functions}

Response functions from appendix (5) shows the industrial sector growth response to random shocks for the growth of ICT was positive until the end of the fifth year, but it became negative in the sixth year. However, by the end of the seventh year, the negative effect tended to decline, that is, the positive effect of random shocks for the growth of ICT on the growth of the industrial sector continued until the end of the tenth year.

It can be concluded that random shocks in the growth of ICT have a positive effect on the growth of the industrial sector in a short period.

Appendix (5) shows that the occurrence of random shocks in the growth of the education sector leads to a positive effect on the growth of the industrial sector because it affects the transmission of the effect from the negative side to the positive side and continues until the tenth year.

Thus, the occurrence of random shocks in the growth of the education sector has a positive effect on the growth of the industrial sector in a short period.

Appendix (5) shows that the occurrence of random shocks in the growth of the education sector leads to a positive effect on the growth of the industrial sector until the seventh year but with the beginning of the eighth year, the negative effect appears and decreases by the end of the eighth year, where the effect of the random shock to the growth of the education sector is positive and continues until the end of the study.

Thus, the occurrence of random shocks in the growth of the education sector has a positive effect on the growth of the industrial sector in a short period.

\section{Analysis of Covariance}

Appendix 6 shows a decrease in the explanatory percentage of the effect of the growth of the industrial sector gradually from the first year until the tenth year compared to the explanatory increase in the growth rates of ICT and the growth of the education sector in explaining the growth of the industrial sector

The explanatory importance of the growth of the ICT sector is clear in explaining the growth of the industrial sector because it increased significantly during ten years at $5.25 \%$ in the second year, and the explanatory percentage continued to decrease gradually until it reached $39.36 \%$ in the tenth year. Thus, a positive relationship between the growth of ICT and the growth of the industrial sector can be observed in the short-term period.

Therefore, the assumption of the existence of a short-term positive relationship between the growth of ICT and the growth of the industrial sector is accepted. 
INTERNATIONAL JOURNAL OF ACADEMIC RESEARCH IN ACCOUNTING, FINANCE AND MANAGEMENT SCIENCES

Vol. 11, No. 1, 2021, E-ISSN: 2225-8329 @ 2021 HRMARS

The interpretation showed that the education sector growth rose from zero to $1.55 \%$ in the second year, and then the percentage decreased to $1.022 \%$ and $0.97 \%$ in the third and fourth years, respectively, but it increased to $1.05 \%$ in the fifth year and continued to rise until it reached 1.27. This pattern indicates that a positive relationship can be found between the effect of the growth of the education sector on the growth of the industrial sector in the short term.

It can be concluded that a positive relationship can be found between the growth of the education sector on the growth of the industrial sector during the short-term period.

Therefore, the assumption that a short-term positive relationship can be found between the growth of the education sector and the growth of the industrial sector is accepted.

Estimating the Study Model through the Results of the Vector Autoregression Model

Where a model was estimated and the results appeared as follows.

Table (4): The effect of the growth of ICT and the education sector on the growth of the industrial sector

Dependent Variable: LOG(TI)

\begin{tabular}{|l|l|l|l|}
\hline Variable & Coefficient & t-Statistic & Prob. \\
\hline LOG(ICT(-2)) & 0.924978 & 8.509917 & 0.0000 \\
\hline LOG(ES(-2)) & 0.179572 & 3.822104 & 0.0034 \\
\hline C & -0.189385 & -0.079811 & 0.9380 \\
\hline
\end{tabular}

source: Prepared by the researcher using the E-views program based on the study data in Appendix No. (1).

R- Squared: $89.8 \%$.

Adjusted R-Squared: $87.78 \%$.

F-Statistic: $\mathbf{4 4 . 1 2}$

Prob(F-statistic): 0.000011

Durbin-Watson stat: 1.34

The model shows the coefficient of determination (modified $\mathrm{R}$ squared $89.8 \%$ ), which means that changes in the independent variables explained approximately $89.8 \%$ of the changes in the dependent variable also, the value of F-statistic reaches 44.12 , and with a probability close to zero, which means that the model is statistically significant as that the Durbin-Watson coefficient was 1.34, indicating that the model is appropriate and statistically significant, and judging the existence of a self-correlation problem or systematic error is not possible.

Can test the feasibility of the model and its ability in Jordan using the dispersion factor criterion (contrast ratio), as shown in Form 6. The researcher performed some standardized tests to ensure reliability, stability, and feasibility (validity test). Form 6 indicates that the bias values (Bias proportion) close to zero. The dispersion coefficient (variance proportion) is $2 \%$, and covariance proportion is $97 \%$. The random errors in the model show that the predictive power of the growth industry sector in Jordan model is acceptable. 
INTERNATIONAL JOURNAL OF ACADEMIC RESEARCH IN ACCOUNTING, FINANCE AND MANAGEMENT SCIENCES

Vol. 11, No. 1, 2021, E-ISSN: 2225-8329 @ 2021 HRMARS

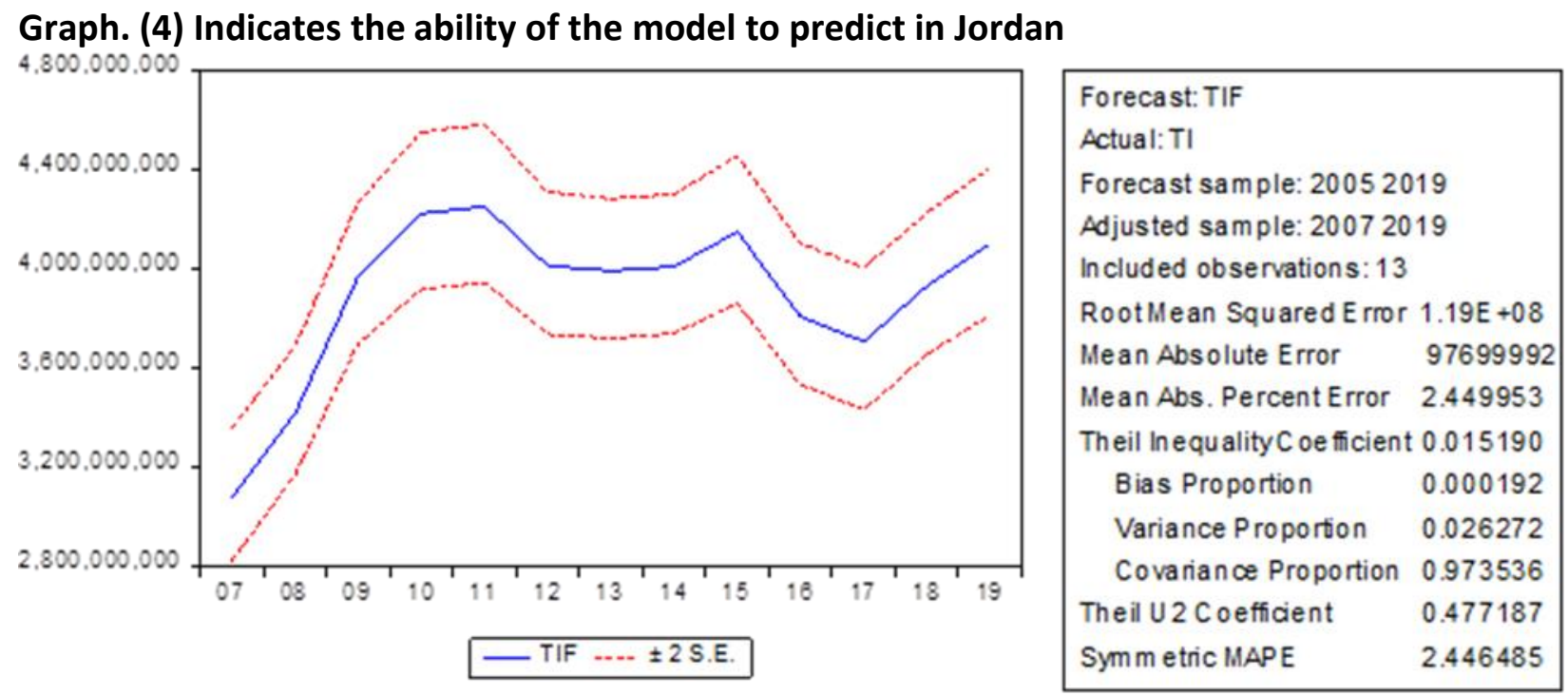

Source: prepared by the researcher using the program E-views based on study data in Appendix (1).

Fourth Hypothesis: A statistically significant positive relationship can be observed at the level of $\alpha \leq$ 0.05 between the growth of ICT and the growth of the industrial sector for companies listed on the Amman Stock Exchange.

Table (5): the estimated coefficient to growth of ICT

\begin{tabular}{|l|l|l|l|}
\hline Variable & Coefficient & t-Statistic & Prob. \\
\hline LOG(ICT(-2)) & 0.924978 & $\mathbf{8 . 5 0 9 9 1 7}$ & 0.0000 \\
\hline
\end{tabular}

Source: prepared by the researcher based on table no (4).

The standard analysis in Table 5 shows that the estimated coefficient to growth of ICT is equal to $92 \%$, which is a positive signal and means that the relationship between the change in growth of ICT and the change in the growth of the industrial sector is positive. This finding is consistent with the economic and financial literature that emphasizes a positive relationship between the growth of ICT and the growth of the industrial sector indicates a statistically positive effect of growth of ICT on the growth of the industrial sector and an increased growth of ICT by $100 \%$, which leads to an increase in the growth of the industrial sector by $92 \%$. This finding can be explained by the growth of the industrial sector that corresponds to the increase in the growth of ICT in the short and long term in Jordan.

The results of the T-test is statistically significant at $1 \%$. The confidence level for this variable is equal to $99 \%$. Therefore, the hypothesis is accepted, that is, a statistically significant positive relationship exists at the level of $\alpha \leq 0.05$ between the growth of ICT and the growth of the industrial sector for companies listed on the Amman Stock Exchange. 
INTERNATIONAL JOURNAL OF ACADEMIC RESEARCH IN ACCOUNTING, FINANCE AND

MANAGEMENT SCIENCES

Vol. 11, No. 1, 2021, E-ISSN: 2225-8329 @ 2021 HRMARS

3.2.1. fifth hypothesis: A statistically significant positive relationship can be observed at the level of $\alpha \leq 0.05$ between the growth of the education sector and the growth of the industrial sector for companies listed on the Amman Stock Exchange.

Table (6): the estimated coefficient to growth of the education sector

\begin{tabular}{|l|l|l|l|}
\hline Variable & Coefficient & t-Statistic & Prob. \\
\hline LOG(ES(-2)) & $\mathbf{0 . 1 7 9 5 7 2}$ & $\mathbf{3 . 8 2 2 1 0 4}$ & $\mathbf{0 . 0 0 3 4}$ \\
\hline
\end{tabular}

Source: prepared by the researcher based on table no (4).

The standard analysis in Table 6 shows that the estimated coefficient to growth of the education sector is equal to $92 \%$, which is a positive signal and means that the relationship between the change in growth of the education sector and the change in the growth of the industrial sector is positive. This finding is consistent with the economic and financial literature that emphasizes a positive relationship between the growth of the education sector and the growth of the industrial sector indicates a statistically positive effect of growth of the education sector on the growth of the industrial sector and an increased growth of the education sector by $100 \%$, which leads to an increase in the growth of the industrial sector by $92 \%$. This finding can be explained by the growth of the industrial sector that corresponds to the increase in the growth of the education sector in the short and long term in Jordan.

The results of the T-test is statistically significant at $1 \%$. The confidence level for this variable is equal to $99 \%$. Therefore, the hypothesis is accepted, that is, a statistically significant positive relationship exists at the level of $\alpha \leq 0.05$ between the growth of the education sector and the growth of the industrial sector for companies listed on the Amman Stock Exchange.

\section{Autocorrelation test, Variance test, and Variance Inflation Factors test for the model Autocorrelation Teste}

Autocorrelation is tested by the E-views program using the Breusch-Godfrey serial correlation Lagrange multiplier (LM) test to check the problem of autocorrelation in the model. Appendix (7) show that the Chi-square probability at lags (2) are greater than $5 \%$, which indicates the absence of the autocorrelation problem in the model

\section{Variance Teste}

Variance is tested by the E-views Program using the autoregressive conditional heteroskedasticity test $(\mathrm{ARCH})$ to check the problem of variance in the model. Appendix (8) that the Chi-square probability at lags (2) are greater than $5 \%$, which indicates the absence of variance instability in the model

\section{Variance Inflation Factors test}

The independence of the variables listed in appendix (9) are also tested and the results indicate the independence of the independent variables and the uncentered VIF is greater than 10, which indicates the independence of the independent variables. 
INTERNATIONAL JOURNAL OF ACADEMIC RESEARCH IN ACCOUNTING, FINANCE AND

MANAGEMENT SCIENCES

Vol. 11, No. 1, 2021, E-ISSN: $2225-8329$ @ 2021 HRMARS

\section{Co-integration Test}

To carry out the joint integration, it is necessary to determine the slowdown periods for the study variables and through the tests in appendix 10, which show the slowdown variables at lag (2).

A co-integration of the study variables at lag (2) was also performed as shown in appendix 10 and shows the existence of two co-integration relationships between the study variables, which indicates that a long-term equilibrium relationship can be observed between the study variables. Therefore, the hypothesis is accepted, that is, the growths of the ICT, education, and industrial sectors have a statistically significant long-term co-integration relationship at ( $\alpha \geq 0.05)$.

\section{Results and Recommendations \\ Results}

The VAR analysis revealed that a positive correlation between the study variables can be observed. Analysis of the response functions and analysis of the common variance indicated the existence of the positive effect of the growth of the ICT sector on the growth of the industrial sector in the short term for companies listed on the Amman Stock Exchange. A positive effect was also observed of the growth of the education sector on the growth of the industrial sector in the short term for the companies listed on the Amman Stock Exchange. The regression analysis based on the results of VAR, showed the positive statistically significant effect of the growth of the telecom sector on the growth of the industrial sector. The analysis also showed the positive effect of the growth of the education sector on the growth of the industrial sector for the industrial companies listed on the Amman Stock Exchange. The co-integration analysis also showed the existence of a co-integration relationship between the study variables, which means a long-term equilibrium relationship exists between the growths of the ICT, the education, and the industrial sector.

\section{Recommendations}

The following recommendations can be made based on the results of the study.

Attention should be given to the infrastructure in the growth of the ICT and the education sectors to develop the basic economic sectors in the country, such as the industrial sector. Spending on the growth of the telecommunication sector should be increased. To establish infrastructure needed for its growth with the education sector, technical education should be increased to support and develop the industrial sectors in Jordan. Foreign and local direct investment should be encouraged and focused on technical education to enhance growth in the industrial sector. Human resources should also be developed through education and training on modern technology that would facilitate increased growth directly in all basic sectors in addition to benefiting from the experiences of Southeast Asian countries in education related to the industrial aspect. It also needs to follow in the advantage of East Asian countries, such as Japan and South Korea, by relying on education, technology, and communications for the growth of the industrial sector. Furthermore, providing business incubator and non-traditional educational opportunities and stimulating innovation and creativity for technological productive projects in universities and schools and establishing policies for applied scientific research that leads to technological development require further studies on the growth of service sector components and their effects on the growth of economic sectors in the national economy.

Contribution/ Originality: This study is one of the few studies that examines the growth of the telecommunications sector and its impact on the growth of the industrial sector in developing countries, especially in Jordan, which rely heavily on the telecommunications sector to support and 
INTERNATIONAL JOURNAL OF ACADEMIC RESEARCH IN ACCOUNTING, FINANCE AND MANAGEMENT SCIENCES

Vol. 11, No. 1, 2021, E-ISSN: 2225-8329 @ 2021 HRMARS

grow economic sectors. The study also provides a scientific addition in the field of financial and economic sciences from a scientific point of view. Through the use of different statistical methods and from a practical point of view to plan future economic and financial policies, as well as make financial decisions in the country. The study also helps decision-makers in developing the industrial sector in the country

\section{Reference}

Adel, M. A. (2013).The Contribution of Education to the Economic Development Process in Arab Countries, Journal of the Baghdad College of Economic Sciences University, 35, PP 47-66 on line: https://knowledge4all.com/admin/Temp/Files/88844de1-6d87-43a1-8f228aa3a106c7e9.pdf

Adekunle, O., \& Fatima, A. P. F. (2020). Innovations in Teaching and Learning: Exploring the Perceptions of the Education Sector on the 4th Industrial Revolution (4IR), J. Open Innov. Technol. Mark. Complex. 6(2), 31,pp1-22. doi:10.3390/joitmc6020031. On line : file://C:/Users/LENOVO/Downloads/JOItmC-06-00031\%20(3).pdf

Aghaei, M., \& Rezagholizadeh, M. (2017) .The impact of information and communication technology (ICT) on economic growth in the OIC countries, Economic and Environmental Studies (E\&ES),17(2),pp.257-278.On line : https://www.econstor.eu/bitstream/10419/178970/1/ees_17_2_07.pdf

Bousaba, H., \& Sari, M.(2016).The Impact of Financial Performance on the Growth of Algerian Private Industrial Companies "An Empirical Study during the Period (2009-2012), Journal of Al-Quds Open University for Research and Studies, 38 (1), p289.

Chong-S, K., \& Min-K, G. H. (2010).Education Policy and Industrial Development: The Cases of Korea and Mexico, JOURNAL OF INTERNATIONAL AND AREA STUDIES , 17( 2), pp.21-30 on line : file:///C:/Users/LENOVO/Downloads/507-1926-1-PB.pdf

Dalia, M. S. (2017). The Impact of Services Sector on the Industrial Sector and Economic Growth in Palestine 2000-2016, Master Thesis, Faculty of Commerce, Islamic University, Gaza.pp1-138. online:https://iugspace.iugaza.edu.ps/bitstream/handle/20.500.12358/16964/file_1.pdf?seq uence $=1 \&$ isAllowed $=y$

Eric, A. H., \& Ludger, W. (2007). The Role of Education Quality in Economic Growth*, World Bank Policy Research Working Paper 4122, Public Disclosure Authorized, WPS4122, pp 1-80, on line : http://documents1.worldbank.org/curated/en/260461468324885735/pdf/wps4122.pdf

Faris, A., Syed, A. J., \& Mohamed, E. (2019). The impact of ICT on financial development: Empirical evidence from the Gulf Cooperation Council countries, international Journal of Engineering Business Management . 11,PP 1-14 On line :

https://journals.sagepub.com/doi/pdf/10.1177/1847979019870670

Francis, C. A. (2020). Entrepreneurship Education Curriculum and Framework for Its Implementation in Tertiary Institutions in Nigeria: Implication for Developing Entrepreneurial Mindset of Students, journal of Economics and Sustainable Development, 11(22), pp40-56. On line: file:///C:/Users/LENOVO/Downloads/54803-58624-1-PB.pdf

Maryam, F., Rahmah, I., \& Masood, F. (2012). Information and Communication Technology Use and Economic Growth, 7 ( 11 ) on line : www.plosone.org .

Mohun, P., Odit, K. D., \& Fauzel, S. (2010). The Impact Of Education On Economic Growth: The Case Of Mauritius, International Business \& Economics Research Journal, 9(8).Pp141-152. On line : 
INTERNATIONAL JOURNAL OF ACADEMIC RESEARCH IN ACCOUNTING, FINANCE AND

MANAGEMENT SCIENCES

Vol. 11, No. 1, 2021, E-ISSN: 2225-8329 ๑ 2021 HRMARS

file:///C:/Users/LENOVO/Downloads/The_Impact_Of_Education_On_Economic_Growth_The Cas\%20(1).pdf.

Nashat, K. Q. A. ( 2017). The Contribution of The ICT Sector In The Economic Development Process Case Study On Palestinian Companies In Gaza, Master Thesis, College of Commerce, Gazapp ,pp1-110. On line: https://iugspace.iugaza.edu.ps/bitstream/handle/20.500.12358/17068/file_1.pdf?sequence= 1\&isAllowed $=y$

Pradhan, R. P., Mallik, G., \& Tapan, P. B. (2018). Information communication technology (ICT) infrastructure and economic growth: A causality evinced by cross-country panel data. IIMB Management Review , 30, pp91-103 . on line: file:///C:/Users/LENOVO/Downloads/OA\%20full\%20text.pdf

Raéf, B., \& Alaa, A. Q. (2019).Impact of Information and Communication Technology on Economic Growth: Evidence from Developing Countries, Economies Article, $7($ 21); doi:10.3390/economies7010021 ,www.mdpi.com/journal/economies,pp1-22. On line file://C:/Users/LENOVO/Downloads/economies-07-00021.pdf.

Shukiri, N. I. M., \& Walid, A. S. (2009). Measuring the efficiency of the Amman Financial Market through the effect of the size of the company on the return and risk, an applied study on a sample of the industrial companies listed in the Amman Stock Exchange. Baghdad College of Economic Sciences, the nineteenth edition on line : https://www.iasj.net/iasj/download/d39969f82d50b7c9

\section{Website}

Amman Financial Market online: -https://www.ase.com.jo/ar/history?history_category=65

Al-Rai Newspaper. (2014). Education and Development. website: http://alrai.com/article/683258.htmlarticle/683258.html

Ghada, H. (2020) Industry in Jordan, website https://mawdoo3.com/https://mawdoo3.com

Ministry of Digital Economy, Information Technology in Jordan, website.،https://www.modee.gov.jo/AR/Pages

The World Bank. (2009), The Road Not Traveled Education Reform in the Middle East and North Africa, The International Bank for Reconstruction and Development. website:http://documents1.worldbank.org/curated/en/830221468051869802/pdf/467890AR ABICOT101OFFICIALOUSEOONLY1.pdf 
INTERNATIONAL JOURNAL OF ACADEMIC RESEARCH IN ACCOUNTING, FINANCE AND MANAGEMENT SCIENCES

Vol. 11, No. 1, 2021, E-ISSN: 2225-8329 @ 2021 HRMARS

Appendixes

Appendix:(1) Data of study variables during the period (2005-2019)

$\begin{array}{cccc}\text { years } & \text { TI } & \text { ICT } & \text { ES } \\ 2005 & 2598140415 & 562656699 & 167569115 \\ 2006 & 2623511461 & 615506155 & 188395581 \\ 2007 & 3036869019 & 709710754 & 209059076 \\ 2008 & 3445907186 & 755722235 & 212805910 \\ 2009 & 3801282112 & 760863444 & 213346225 \\ 2010 & 4078177880 & 713460338 & 215393008 \\ 2011 & 4401435385 & 700633089 & 229614677 \\ 2012 & 4184030054 & 686761151 & 261061534 \\ 2013 & 4163601421 & 702857070 & 280011201 \\ 2014 & 3964092994 & 629248228 & 307055701 \\ 2015 & 3946114718 & 607661116 & 316276741 \\ 2016 & 3783628444 & 654926055 & 298534978 \\ 2017 & 3761173287 & 686779460 & 295640255 \\ 2018 & 3980720362 & 654674961 & 292115198 \\ 2019 & 4113007842 & 719184190 & 263036530\end{array}$

https://www.ase.com.jo/ar/history?history_category=65

Appendix (2): Deceleration test for study variables.

\begin{tabular}{|l|l|l|l|l|l|l|}
\hline Lag & LogL & LR & FPE & AIC & SC & HQ \\
\hline 0 & & NA & $\begin{array}{l}3.16 e- \\
07\end{array}$ & -6.453821 & -6.323448 & -6.480618 \\
& 44.94984 & & 07 & & \\
\hline 1 & & & $6.73 e-$ & -10.36446 & -9.842963 & -10.47165 \\
& 79.36896 & $47.65725 *$ & 09 & & & \\
\hline 2 & & 16.57485 & $2.34 e-$ & - & - & $-11.92990 *$ \\
& 97.32505 & & $09 *$ & $11.74232 *$ & $10.82970 *$ & \\
\hline
\end{tabular}

source: Prepared by the researcher using the E-views program based on the study data in Appendix no. (1). 
INTERNATIONAL JOURNAL OF ACADEMIC RESEARCH IN ACCOUNTING, FINANCE AND MANAGEMENT SCIENCES

Vol. 11, No. 1, 2021, E-ISSN: 2225-8329 @ 2021 HRMARS

Appendix (3): Analysis of the Vector Autoregression Model

\begin{tabular}{|c|c|c|c|}
\hline & LOG(TI) & LOG(ICT) & LOG(ES) \\
\hline \multirow[t]{3}{*}{ LOG(TI(-1)) } & 0.377821 & 0.445977 & -0.210217 \\
\hline & $(0.26032)$ & $(0.49708)$ & $(0.36573)$ \\
\hline & [ 1.45140$]$ & {$[0.89720]$} & {$[-0.57479]$} \\
\hline \multirow[t]{3}{*}{ LOG(TI(-2)) } & 0.017379 & -0.424538 & 0.632128 \\
\hline & $(0.19965)$ & $(0.38124)$ & $(0.28050)$ \\
\hline & {$[0.08705]$} & {$[-1.11357]$} & [ 2.25356] \\
\hline \multirow[t]{3}{*}{ LOG(TC(-1)) } & 0.021621 & 0.158910 & 0.257116 \\
\hline & $(0.20363)$ & $(0.38883)$ & $(0.28608)$ \\
\hline & {$[0.10618]$} & [ 0.40869] & {$[0.89875]$} \\
\hline \multirow[t]{3}{*}{ LOG(TC(-2)) } & 0.464204 & -0.243164 & -0.411521 \\
\hline & $(0.20230)$ & $(0.38630)$ & $(0.28422)$ \\
\hline & [ 2.29460] & {$[-0.62947]$} & {$[-1.44788]$} \\
\hline \multirow[t]{3}{*}{ LOG(ES(-1)) } & -0.208393 & -0.330904 & 0.967574 \\
\hline & $(0.22482)$ & $(0.42929)$ & $(0.31585)$ \\
\hline & {$[-0.92695]$} & {$[-0.77082]$} & [ 3.06337] \\
\hline \multirow[t]{3}{*}{ LOG(ES(-2)) } & 0.200484 & 0.182612 & -0.416610 \\
\hline & $(0.16686)$ & $(0.31863)$ & (0.23443) \\
\hline & [ 1.20150$]$ & {$[0.57312]$} & {$[-1.77711]$} \\
\hline \multirow[t]{3}{*}{$\mathrm{C}$} & 3.653299 & 24.45218 & 2.549229 \\
\hline & (3.92947) & (7.50338) & $(5.52066)$ \\
\hline & {$[0.92972]$} & [ 3.25882] & {$[0.46176]$} \\
\hline R-squared & 0.958146 & 0.678483 & 0.969497 \\
\hline $\begin{array}{l}\text { Adj. R- } \\
\text { squared }\end{array}$ & 0.916291 & 0.356967 & 0.938994 \\
\hline $\begin{array}{l}\text { Sum sq. } \\
\text { resids }\end{array}$ & 0.004603 & 0.016784 & 0.009086 \\
\hline S.E. equation & 0.027698 & 0.052890 & 0.038914 \\
\hline F-statistic & 22.89234 & 2.110259 & 31.78343 \\
\hline Log likelihood & 33.20268 & 24.79363 & 28.78275 \\
\hline Akaike AIC & -4.031182 & -2.737481 & -3.351192 \\
\hline Schwarz SC & -3.726978 & -2.433278 & -3.046989 \\
\hline
\end{tabular}


INTERNATIONAL JOURNAL OF ACADEMIC RESEARCH IN ACCOUNTING, FINANCE AND MANAGEMENT SCIENCES

Vol. 11, No. 1, 2021, E-ISSN: 2225-8329 (C) 2021 HRMARS

\begin{tabular}{|l|l|l|l|}
\hline $\begin{array}{l}\text { Mean } \\
\text { dependent }\end{array}$ & 22.07939 & 20.35160 & 19.36901 \\
\hline $\begin{array}{l}\text { S.D. } \\
\text { dependent }\end{array}$ & 0.095733 & 0.065956 & 0.157550 \\
\hline
\end{tabular}

Source: Prepared by the researcher using the E-views program based on the study data in Appendix no. (1).

Appendix (4): The stability of the VAR model

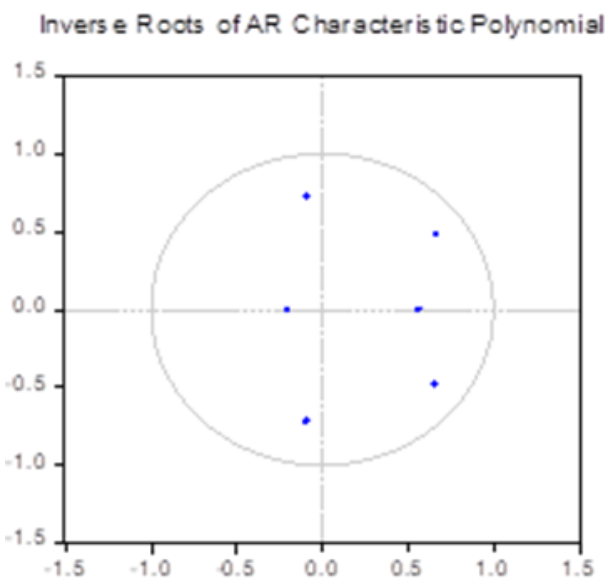

source: Prepared by the researcher using the E-views program based on the study data in Appendix no. (1). 
INTERNATIONAL JOURNAL OF ACADEMIC RESEARCH IN ACCOUNTING, FINANCE AND MANAGEMENT SCIENCES

Vol. 11, No. 1, 2021, E-ISSN: 2225-8329 @ 2021 HRMARS

\section{Appendix (5): Response function}

Response to CholeshyOne S.D. (d.t. adjusted) Inno vationst2 S.E.

Resporse di LOG(TI) to LOG(Ti)

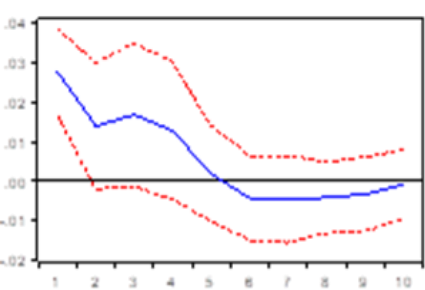

Response of $\operatorname{LOG}(T C)$ ) $\operatorname{LOG}(\mathrm{TI})$

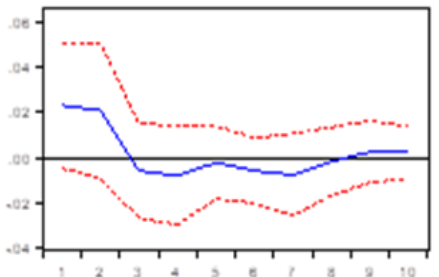

Respores of LOG(ES) to LOG(TI)

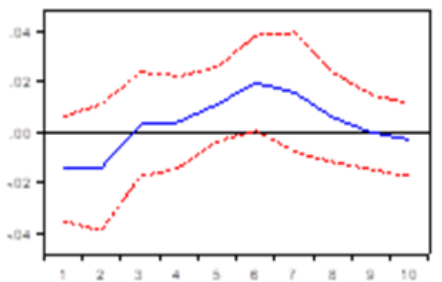

Resporse of $\operatorname{LOG}(\mathrm{TI})$ so $\operatorname{LOG}(\mathrm{TC})$

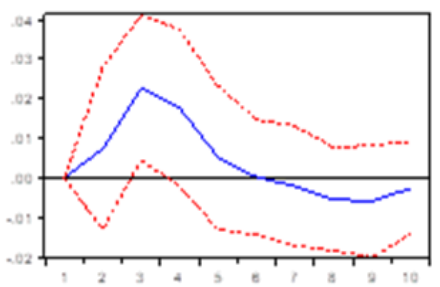

Resporse of $\operatorname{LOG}(T C)$ w $L O G(T C)$

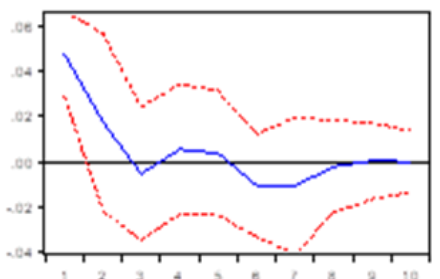

Respores d' LOG(ES) to LOG(TC

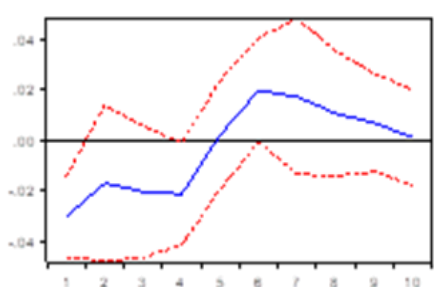

Resporse of $\operatorname{LOG}(\mathrm{TI})$ to LOG(ES)

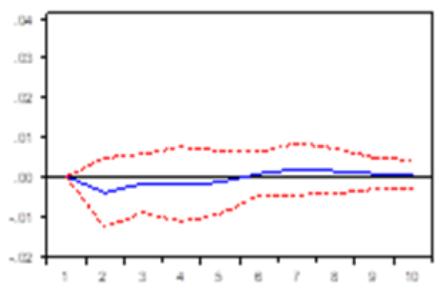

Respone of LOG(TC) to LOG(ES

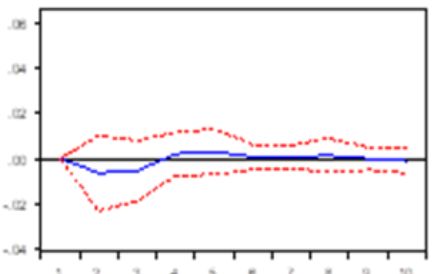

Resporve of LOG(ES) to LOG(ES

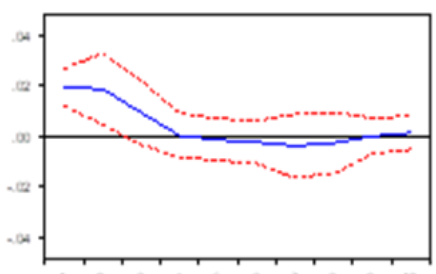

source: Prepared by the researcher using the E-views program based on the study data in Appendix no. (1).

Appendix (6): Analysis of covariance

\begin{tabular}{|c|c|c|c|c|}
\hline \multicolumn{5}{|c|}{$\begin{array}{c}\text { Variance Decomposition of } \\
\text { LOG(TI): }\end{array}$} \\
\hline Period & S.E. & LOG(TI) & LOG(ICT) & LOG(ES) \\
\hline 1 & 0.027698 & 100.0000 & 0.000000 & 0.000000 \\
\hline 2 & 0.032166 & 93.19300 & 5.256660 & 1.550338 \\
\hline 3 & 0.042918 & 67.94876 & 31.02845 & 1.022797 \\
\hline 4 & 0.048167 & 60.99614 & 38.02642 & 0.977438 \\
\hline 5 & 0.048495 & 60.34893 & 38.59771 & 1.053355 \\
\hline 6 & 0.048686 & 60.63475 & 38.29523 & 1.070029 \\
\hline 7 & 0.048976 & 60.76752 & 38.01905 & 1.213434 \\
\hline 8 & 0.049475 & 60.21744 & 38.51049 & 1.272068 \\
\hline 9 & 0.049941 & 59.51559 & 39.21077 & 1.273640 \\
\hline 10 & 0.050020 & 59.35390 & 39.36942 & 1.276672 \\
\hline
\end{tabular}

Variance Decomposition of LOG(TC): 
INTERNATIONAL JOURNAL OF ACADEMIC RESEARCH IN ACCOUNTING, FINANCE AND MANAGEMENT SCIENCES

Vol. 11, No. 1, 2021, E-ISSN: 2225-8329 @ 2021 HRMARS

source: Prepared by the researcher using the E-views program based on the study data in Appendix no. (1).

Appendix (7): Autocorrelation teste

Breusch-Godfrey Serial Correlation LM Test:

\begin{tabular}{llll}
\hline \hline F-statistic & 2.587774 & Prob. $F(2,8)$ & 0.1359 \\
Obs*R-squared & 5.106590 & Prob. Chi-Square(2) & 0.0778 \\
\hline \hline
\end{tabular}

source: Prepared by the researcher using the E-views program based on the study data in Appendix no. (1).

Appendix (8): Variance teste

Heteroskedasticity Test: ARCH

\begin{tabular}{llll}
\hline \hline F-statistic & 0.014453 & Prob. F $(1,10)$ & 0.9067 \\
Obs*R-squared & 0.017319 & Prob. Chi-Square(1) & 0.8953 \\
\hline \hline
\end{tabular}

source: Prepared by the researcher using the E-views program based on the study data in Appendix no. (1).

\section{Appendix (9): Variance Inflation Factors test}

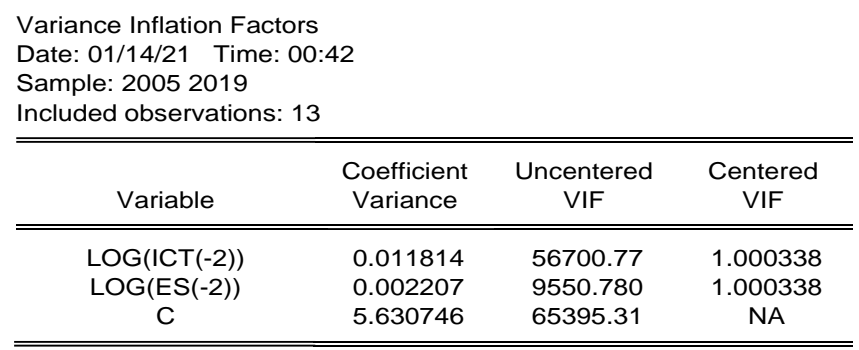

source: Prepared by the researcher using the E-views program based on the study data in Appendix no. (1). 
INTERNATIONAL JOURNAL OF ACADEMIC RESEARCH IN ACCOUNTING, FINANCE AND MANAGEMENT SCIENCES

Vol. 11, No. 1, 2021, E-ISSN: 2225-8329 @ 2021 HRMARS

\section{Appendix (10): Co-integration test}

Date: 01/29/21 Time: 08:57

Sample (adjusted): 20082019

Included observations: 12 after adjustments

Trend assumption: No deterministic trend

Series: LOG(TI) LOG(ICT) LOG(ES)

Lags interval (in first differences): 1 to 2

Unrestricted Cointegration Rank Test (Trace)

\begin{tabular}{ccccc}
\hline \hline $\begin{array}{c}\text { Hypothesized } \\
\text { No. of CE }(\mathrm{s})\end{array}$ & Eigenvalue & $\begin{array}{c}\text { Trace } \\
\text { Statistic }\end{array}$ & $\begin{array}{c}0.05 \\
\text { Critical Value }\end{array}$ & Prob. $^{* *}$ \\
\hline \hline None * & 0.962062 & 53.53961 & 24.27596 & 0.0000 \\
At most 1 & 0.690085 & 14.27795 & 12.32090 & 0.0232 \\
At most 2 & 0.018204 & 0.220458 & 4.129906 & 0.6959 \\
\hline \hline
\end{tabular}

Source: Prepared by the researcher using the E-views program based on the study data in Appendix no. (1). 